\title{
How will China's central-local governmental relationships evolve? An analytical framework and its implications
}

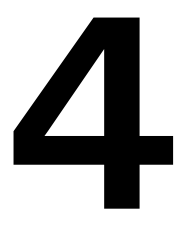

Yongsheng Zhang

\section{Introduction}

The way in which intergovernmental relationships evolve in China is crucial for China's future development. There has been a worldwide trend towards decentralisation of power and responsibilities in large countries since the 1980s. Nonetheless, decentralisation does not necessarily mean a weakened capability of the central (or federal) government to control the behaviour and actions of local governments.

From a fiscal perspective, decentralisation has three related dimensions: responsibility for expenditure; responsibility for raising revenue; and intergovernmental fiscal transfer payments. For each level of government, the relationship between these three items is: expenditure = own-source revenue + intergovernmental fiscal transfer payments.

If decentralisation means an increase in own-source revenue (or taxation autonomy) of lower-level governments then it would result in a reduction of transfer payments. In this situation, the local government's fiscal capability is improved and the central government's is weakened. If decentralisation instead means the devolution of expenditure responsibility then it could be achieved either through an increase in fiscal transfer payments or an increase in the taxation autonomy of lower-level governments. In the former case, the central government's controlling capability is enhanced with decentralisation, while in the latter it is the local government's controlling capability that is enhanced. Therefore, different forms of decentralisation have very different implications for each level of government in terms of controlling capability.

The key principle of decentralisation is broadly accepted: jurisdiction over the delivery of public services should be allocated to the level of government closest to the citizen, unless such delivery can be taken on more effectively by a government that is further away. Accordingly, local governments should have more fiscal autonomy. Nonetheless, it has been a fact that, in most 
countries, higher levels of government control most of the fiscal resources. The worldwide trend towards decentralisation in recent decades is reflected mainly in expenditure, while on the side of revenue it shows a contrary trend of centralisation. The gap between the expenditure and own-source revenue of local governments is filled by fiscal transfer payments. This brings 'vertical fiscal imbalance', in which lower levels of government become financially reliant on transfer payments from higher levels of government. Thus, through increasing transfer payments, the controlling capability of central governments over local governments has been further enhanced rather than weakened.

Why do most countries - including Western countries (either unitary or federal)-purport to value democracy and decentralised markets, yet adopt highly centralised fiscal arrangements? Most of the existing explanations focus on inter-regional externalities relating to infrastructure, spill-overs or regional fiscal equalisation. The solution to these problems is seen to lie in higher levels of government having sufficient fiscal capability (for example, Oates 1972; Seabright 1996). It is not so obvious, however, that central governments need to control most of their country's fiscal revenue in order to solve these problems. For example, trans-regional infrastructure projects could be provided through negotiation between the relevant stakeholders (à la Coase), rather than relying on the central government. Indeed, trans-regional infrastructure projects that are provided by the central government create an additional externality, since in this situation other regions not benefiting from the project bear a part of the tax burden as well. Second, in industrialised countries in which spatial economic imbalances are small, the central governments also control most of the nation's fiscal revenues. As for fiscal equalisation, in industrialised countries in which spatial imbalances are small, the costs of transfer payments often exceed the benefits, particularly when transaction costs are taken into account. Yet even these countries tend to have highly centralised fiscal arrangements. There must be a fundamental explanation for this.

And there is. The fiscal relationship is only one dimension of intergovernmental relationships, and the above explanations fail to take into account the other dimensions, such as the personnel dimension. The objective of this chapter is to provide a new analytical framework for intergovernmental relationships and to investigate its implications for the future evolution of China's central-local governmental relationships. The next section provides a brief review of the relevant literature on intergovernmental relationships. After that, an analytical framework on intergovernmental relationships is presented and some supportive evidence is provided. Subsequent sections consider the current status of China's intergovernmental relationships and how they might evolve in the future. The last section concludes the chapter and suggests how the framework can be applied to a large research agenda in the future. 


\section{Intergovernmental relationships: a brief literature review}

There are three lines of research on intergovernmental relationships from the perspective of vertical fiscal imbalances. First, according to classic fiscal theories (represented by Musgrave 1959 and Oates 1972, among others), a strong central government is necessary to achieve three nationwide goals: efficient resource allocation, equity and economic stability. These theories cannot, however, provide an accurate answer to the question of how much fiscal revenue the central government needs to control, either in absolute terms or as a proportion of all revenue. It seems, according to these theories, that either unbalanced or balanced vertical fiscal relations could occur, since the centre's expenditure responsibility for the three goals might be achieved with a lower central fiscal capability, which makes a balanced vertical fiscal relation possible.

The second research line is related to the optimisation of a nation's aggregate tax revenue. It is argued that vertical fiscal imbalances result from optimising a nation's tax revenue for a given economic and taxation structure, stemming from a range of assumptions about incentive mechanisms, fiscal autonomy, accountability, information, tax competition, tax costs and spill-overs. ${ }^{1}$ The implicit assumption is that vertical fiscal imbalance is pre-designed by a central planner to optimise the nation's tax revenue, so that the move towards a more balanced fiscal structure could cause a fall in aggregate tax revenue, encourage inter-regional transfers of tax resources or increase the taxation costs. There are, however, contradictory findings within this line of research, with some authors emphasising the advantages of decentralisation and others emphasising the advantages of centralisation.

The third line comes from the perspective of constitutional economics. There are three branches in this line. The first emphasises the advantages of decentralisation as a mechanism to control inefficient central governments, in which local governments are like clubs established by the local population to solve common problems (for example, Buchanan 1965; Brennan and Buchanan 1980; North 1987). Beneficial taxation - in which tax is paid according to the benefits received from the system - assures local accountability and there is no case for the central government's financial controls. This branch advocates fiscal autonomy of the local governments, while remaining alert to the potential for their opportunistic behaviour. Implicitly, this means that central governments will not be encouraged to control most fiscal resources and then to refund local governments through transfer payments. The second branch emphasises the

1 See, for instance, Breton (1996); King (1984); Scott (1952); Hicks (1984); Courant et al. (1979); Boadway and Tremblay (2005). 
advantages of federal governments, as represented by Hamilton et al. (1787). In Hamilton's time, the biggest challenge for the American federalists was to establish a federal government from the confederation. They did not propose that the federal government control most of the nation's fiscal revenue; rather they repeatedly vowed that the power of the federal government should be strictly limited. Their basic position, however, was to emphasise the advantages of a strong federal government. We treat their position, then, as being procentralisation.

De Figureiredo and Weingast (2005) and Weingast (2005) represent the third branch. They emphasise the importance of the power balance between federal and state governments for a self-enforcing federalism. They begin their studies with two fundamental dilemmas of federalism: too strong a centre risks overwhelming a federation by acting opportunistically and extracting too many rents; too weak a centre risks a federation's collapse due to free-riding and insufficient provision of public goods. The twin dilemmas make stable federalism problematic - in part because they imply a trade-off in the structure of a federation. Institutions designed to address one of the dilemmas exacerbate the other. To be stable, federalism requires a delicate balance of central government powers combined with mechanisms for limiting the centre's opportunism. Crisis shocks play a key role in achieving the balance of power (Weingast 2005). The perspective emphasising the balance of powers is consistent with the concept of equilibrium in economics.

\section{A new analytical framework and decentralisation}

Based on the theory of self-enforcing federalism (de Figureiredo and Weingast 2005), Zhang $(2005,2008,2009)$ further develops an analytical framework to coordinate the three branches in constitutional economics. He further divides governmental controlling capability into two major dimensions: the personnel dimension (or democratic dimension) and the fiscal dimension. Whether a federation/nation can be sustainable is conditioned on the game between the national and sub-national governments. For instance, in a democratic nation with elections, the federal/central government has no control over the elected officials of the states. To achieve sustainable federalism, an institutional arrangement enhancing the control of the central/federal government over the sub-national governments is needed. Fiscal transfer payments are then used as a hostage by the federal/central government to influence the states/provinces. Vertical fiscal imbalance and transfer payments then work as hostage mechanisms, with lowerlevel governments heavily financially reliant on the higher level. This provides 
an explanation for why, in most countries, the central government controls most of the nation's fiscal resources and for why higher levels of government control most fiscal resources in their jurisdictions.

Since both personnel and fiscal dimensions could be either bottom-up or top-down, the combinations of these two dimensions consist of four basic structures for vertical intergovernmental relationships (Table 4.1). A vertical intergovernmental relationship will not be sustainable if it is unbalanced. Crisis shocks then play a key role in changing the structure making the nation sustainable (Weingast 2005). Vertical balance can be achieved through a twoway arrangement in personnel and fiscal dimensions. Yet, vertical balance is not sufficient for a nation to achieve good economic performance. Horizontal balance between the government and the market must also be established, which could be realised by checks and balances of a government's power through constitutional rule, as pointed out by Buchanan (1965), Brennan and Buchanan (1980), North (1987) and North and Weingast (1989).

Table 4.1 Different structures of intergovernmental relationships

\begin{tabular}{|l|l|l|l|l|l|}
\hline Structures & $\begin{array}{l}\text { Personnel } \\
\text { dimension }\end{array}$ & $\begin{array}{l}\text { Fiscal } \\
\text { dimension }\end{array}$ & Examples & Result \\
\hline Structure 1 & $\begin{array}{l}\text { I. With good rule } \\
\text { of law }\end{array}$ & $\uparrow \uparrow$ & $\downarrow \downarrow$ & $\begin{array}{l}\text { Western } \\
\text { countries }\end{array}$ & $\begin{array}{l}\text { Sustainable, } \\
\text { efficient }\end{array}$ \\
\cline { 2 - 6 } & $\begin{array}{l}\text { II. Without good } \\
\text { rule of law }\end{array}$ & $\uparrow \uparrow$ & $\downarrow \downarrow$ & $\begin{array}{l}\text { Some Latin } \\
\text { American } \\
\text { countries }\end{array}$ & $\begin{array}{l}\text { Sustainable } \\
\text { but low } \\
\text { efficiency }\end{array}$ \\
\hline Structure 2 & $\uparrow \uparrow$ & $\uparrow \uparrow$ & $\begin{array}{l}\text { European Union, } \\
\text { confederation, } \\
\text { United Nations }\end{array}$ & $\begin{array}{l}\text { Unstable, } \\
\text { inefficient }\end{array}$ \\
\hline Structure 3 & $\downarrow \downarrow$ & $\uparrow \uparrow$ & $\begin{array}{l}\text { Former Soviet } \\
\text { Union-style } \\
\text { countries }\end{array}$ & $\begin{array}{l}\text { Central } \\
\text { planning } \\
\text { regime }\end{array}$ \\
\hline Structure 4 & $\downarrow \downarrow$ & $\uparrow \uparrow$ & $\begin{array}{l}\text { China before } \\
\text { tax-sharing } \\
\text { system reform, } \\
\text { Hong Kong } \\
\text { before 1997 }\end{array}$ & $\begin{array}{l}\text { More } \\
\text { efficient } \\
\text { than } \\
\text { Structure 3 }\end{array}$ \\
\hline
\end{tabular}

Notes: The arrow $\downarrow=$ 'top down'; $\uparrow=$ 'bottom up'. For instance, if the personnel dimension is $\uparrow$, it means local officials are not appointed by higher levels of government. If the fiscal dimension is $\downarrow$, it means higher levels of government control most fiscal resources and can put influence on lower-level governments through transfer payments, and vice versa.

Source: Author's own summary.

In Table 4.1, Structure 1 represents the combination of bottom-up personnel relationships and top-down fiscal relationships. In the personnel dimension, the local government has autonomy (although this does not necessarily mean 'election'; autonomy can also happen in a feudal or authoritarian regime), while 
the higher level of government controls most fiscal resources and the lower-level governments have to rely financially on transfer payments. Most industrialisedmarket countries can be classified as Structure 1. This structure is self-enforcing. It can be further classified into two substructures: Structure 1-(I) with, and Structure 1-(II) without, good rule of law.

Structure 2 is one with a weak federal/central government and is neither stable nor efficient - like the American confederation or the early stage of federation in the United States and Australia.

Structure 3 is one with a strong federal/central government, such as the former Soviet Union countries. The central government is too powerful, controlling fiscal revenue and official appointments to lower-level governments. As de Figureiredo and Weingast (2005:127) indicate, 'too strong a centre risks overwhelming a federation by acting opportunistically and extracting too many rents'. This structure is neither stable nor sustainable in the long run.

Structure 4 is a relatively stable structure - such as fiscal federalism in China before 1994 or the UK-Hong Kong relationship before 1997. To some extent, this structure has established a vertical balance on intergovernmental relationships. Nonetheless, since the centre controls official appointments to local governments, local governments do not have real bargaining power against higher levels of government. The central government might easily change the fiscal arrangement. If the higher-level government was a democratic regime, or the higher-level government could not change its fiscal relationship, this structure could be reasonably sustainable.

Different structures have different effects on preventing governmental opportunistic behaviour. Correspondingly, there are two types of governmental opportunistic behaviour in the framework: vertical and horizontal. Vertical governmental opportunistic behaviour refers to the opportunistic behaviour between different levels of government. A balance of intergovernmental relationships is required to prevent this. Horizontal governmental opportunistic behaviour refers to opportunistic behaviour in the market. The horizontal checks and balances of government power are to prevent this type of governmental opportunistic behaviour.

According to Smith (1776), the division of labour is the springboard for economic growth. Yang (2001) developed an 'inframarginal economic framework' in which the evolution of the division of labour was driven by increased transaction efficiency, especially related to institutions. According to North (1987), economic performance is conditioned on the level of endogenous transaction costs resulting from governmental opportunistic behaviour. His idea can be further extended to two types of vertical and horizontal governmental opportunistic 
behaviour in our analytical framework. A sustainable and stable structure, and therefore also a pro-economic development structure, must be a structure that can minimise the two types of governmental opportunistic behaviour. Among the four structures, Structure 1 is the most self-enforcing structure with the least endogenous transaction costs. Structures 2 and 3 are not self-enforcing in the long run. Structure 4 is not as stable as Structure 1.

The framework developed in this chapter can be applied to explain the worldwide decentralisation trend in recent decades. There are good examples of decentralisation, but also bad ones (Martinez-Vazquez and McNab 2003; Fisman and Gatti 2002). Decentralisation has resulted in macroeconomic volatility in some countries but not in others. According to Stein (1999), decentralisation did not increase the fiscal deficits of local governments. According to Fornasari et al. (2000) and de Melo (2000), however, the expansion of local governmental expenditure and deficits after decentralisation results in the expansion of central governmental expenditures and deficits. According to Fisman and Gatti (2000), there is a high correlation between decentralisation and corruption. Simply devolving fiscal power from central governments to regional elites without institutional reforms would encourage corruption. Nonetheless, Treisman (2000) shows no correlation between decentralisation and corruption. Faguet (2004) shows that decentralisation has not increased corruption, but instead makes local governments more responsible.

Why are the apparent effects of decentralisation so varied and contradictory? Why has decentralisation had positive effects in some countries, but not in others? According to our analytical framework, the effectiveness of decentralisation in a nation depends on whether decentralisation makes the intergovernmental structure more sustainable and whether it reduces the endogenous transaction costs resulting from the two types of governmental opportunistic behaviours. Specifically, decentralisation will bring more effectiveness under the following conditions.

First, decentralisation should not change the vertical intergovernmental balance. Within Structure 1(I), decentralisation would be effective. Nonetheless, if decentralisation goes too far and the local government has too much taxation autonomy, Structure 1(I) will jump to Structure 2. Consequently, decentralisation will cause more opportunistic behaviour from local governments and affect the stability and economic performance of the nation. Hence, no matter how decentralised it is, remaining within Structure $1(\mathrm{I})$ is the bottom line of decentralisation for Western countries. Accordingly, the local government's expenditure should be expanded mainly through fiscal transfer payments, rather than through devolving more tax autonomy. Second, government power must 
be limited and checked and balanced in the process of decentralisation, so that the devolved powers do not increase the horizontal governmental opportunistic behaviour of the local governments.

Thiessen (2003) provides evidence of how the effects of decentralisation change with the extent and type of decentralisation. His studies of the Organisation for Economic Cooperation and Development (OECD) show that fiscal decentralisation from a highly centralised starting point results in improved economic performance. Further decentralisation beyond a certain level, however, results in negative effects.

This analytical framework can be used to understand a wide range of decentralisation experiences in time and space, with this section briefly describing just two: the United States and Australia.

Since its independence in 1776, the United States, in its federal-state government relationships, has experienced different stages: confederation without national government $\rightrightarrows$ federation with weak federal government $\rightrightarrows$ strong federal government after the Great Depression and World War II $\rightrightarrows$ decentralisation. During the period 1776-87, there was no federal government in the United States. Before the Great Depression, the federal government was very weak. This was a typical Structure 2 and was not sustainable. From the Great Depression through to the 1980s, the fiscal capability of the federal government has been significantly enhanced and the vertical intergovernmental relationship jumped from Structure 2 to Structure 1. Since the 1980s, the decentralisation of expenditure has become a worldwide trend, including in the United States. Nonetheless, fiscal decentralisation happened mainly for expenditure, rather than with regard to the fiscal autonomy of local governments. US intergovernmental relations have remained in Structure 1 during the process of decentralisation, and the federal government always controls most of the nation's fiscal resources and imposes influence through fiscal transfer payments (Wallin 2001; Fox 2001). Throughout the evolution of intergovernmental relationships in the United States, crises and shocks have been crucial driving forces (Weingast 2005).

The evolution of federal-state relations in Australia has been similar to that in the United States: the capability of the federal government has grown stepby-step and the evolution of Australian federal-state relationships is a process moving from Structure 2 to Structure 1. As the six colonies formed a federation on 1 January 1901, the federal government merely had some enumerated powers on international affairs such as defence, trade and immigration, while its fiscal capability was weak. The states provided crucial public services such as education, health and law and order, and reserved all residual rights (Watts 1999). In this case, most people expected that the Australian Constitution provided a guarantee to make the states financially independent of the federal 
government. Nonetheless, it turned out differently. The early Australian federal-state relationship of Structure 2 was not a self-enforcing federation. It faced the fate of either evolving to Structure 1 or dissolving. The driving force for the evolution was a series of crisis shocks, including two world wars, the Great Depression and a number of domestic crises. In Structure 1, the federalstate relationship became stable and sustainable and the federation became selfenforcing (see Dollery 2002).

\section{China's vertical intergovernmental relations: past and current status}

\section{Central-provincial government relations}

In China, in the planned economy before 1978, the central-provincial relationship fell into Structure 3. The central government was like a command centre. It not only controlled the appointment of major provincial officials, it controlled the fiscal resources of the provinces. The fiscal system was called a 'unified collection and allocation of funds by the state' (Tongshoutongzhi). The central government controlled the collection and allocation of fiscal resources.

Between 1978 and 1994, China adopted a fiscal responsibility system whereby local authorities took full responsibility for their revenues and expenditures, which was known as 'fenzaochifan' - that is 'each province eats the rice in its own bowl' — or fiscal federalism (Qian and Weingast 1997). This changed China's central-provincial relationship from Structure 3 to Structure 4. In Structure 4 , the central government controlled the appointment of major officials in the provinces, but no longer controlled each province's fiscal revenue. According to Qian and Roland (1998), Qian and Weingast (1997) and Shirk (1993), the introduction of fiscal federalism provided strong incentives for the provinces to develop their economies. This resulted in most fiscal resources in China being controlled by the provinces. The fiscal capability of the Chinese central government was insufficient. For instance, in 1993, the share of central government revenue accounted for only 22 per cent of the nation's total tax revenue (Table 4.2). 
China: The Next Twenty Years of Reform and Development

Table 4.2 Share of central and local governments in government revenue and expenditure (per cent)

\begin{tabular}{l|c|c|c|c}
\hline \multirow{2}{*}{ Year } & \multicolumn{2}{|c|}{ Revenue } & \multicolumn{2}{|c}{ Expenditure } \\
\cline { 2 - 5 } & Central & Local & Central & Local \\
\hline 1978 & 15.5 & 84.5 & 47.4 & 52.6 \\
1980 & 24.5 & 75.5 & 54.3 & 45.7 \\
1985 & 38.4 & 61.6 & 39.7 & 60.3 \\
1990 & 33.8 & 66.2 & 32.6 & 67.4 \\
1991 & 29.8 & 70.2 & 32.2 & 67.8 \\
1992 & 28.1 & 71.9 & 31.3 & 68.7 \\
1993 & 22.0 & 78.0 & 28.3 & 71.7 \\
1994 & 55.7 & 44.3 & 30.3 & 69.7 \\
1995 & 52.2 & 47.8 & 29.2 & 70.8 \\
1996 & 49.4 & 50.6 & 27.1 & 72.9 \\
1997 & 48.9 & 51.1 & 27.4 & 72.6 \\
1998 & 49.5 & 50.5 & 28.9 & 71.1 \\
1999 & 51.1 & 48.9 & 31.5 & 68.5 \\
2000 & 52.2 & 47.8 & 34.7 & 65.3 \\
2001 & 52.4 & 47.6 & 30.5 & 69.5 \\
2002 & 55.0 & 45.0 & 30.7 & 69.3 \\
2003 & 54.6 & 45.4 & 30.1 & 69.9 \\
2004 & 54.9 & 45.1 & 27.7 & 72.3 \\
2005 & 52.3 & 47.7 & 25.9 & 74.1 \\
2006 & 52.8 & 47.2 & 24.7 & 75.3 \\
2007 & 54.1 & 45.9 & 23.0 & 77.0 \\
2008 & 53.3 & 46.7 & 21.3 & 78.7 \\
\hline
\end{tabular}

Source: National Bureau of Statistics (NBS) 2009, China Statistical Yearbook 2009, China Statistics Press, Beijing, p. 263.

Since the central government lacked fiscal capability, towards the end of the 1980s and in the early 1990s, it 'borrowed' money from the provinces twice and was eventually unable to repay that money (Sun 2004). Before the introduction of the Tax Sharing System (TSS) reform in 1994, there were some specific topdown fiscal grants from the central government to the provinces, but there were also bottom-up 'transfer payments' from the provinces to the centre. In contrast with Western national governments, the Chinese central government was somehow financially reliant on the provinces to support its expenditure before 1994.

Structure 4 provided a relatively balanced vertical relationship between the centre and provinces, in which the provinces had more autonomy and stronger 
incentives to promote their own economies. Nonetheless, this was not a normal intergovernmental relationship within a nation and the central government had both the incentive and the ability to change it.

Third, having experienced fiscal incapability for more than a decade, the central government eventually became determined to change the bottom-up fiscal arrangement and establish a top-down fiscal arrangement through the TSS reform in 1994. According to the TSS, the ratio of the major tax sources between the central and provincial governments is 75:25. This has resulted in the rapid growth of the central government's revenue (Table 4.2). The relationship between the central government and the provinces jumped from Structure 4 to Structure 3. In Structure 3, the central government not only controls the appointment of major provincial officials, it controls a large share of provincial fiscal revenue through transfer payments. The provinces have to rely heavily on transfer payments from the central government.

The rapid increase of the central government's revenue came mainly from incremental tax revenue, not from redistribution of the existing tax revenue. There was an agreement between the central and provincial governments that the TSS reform would not change the status of fiscal revenue of each province. Since the Chinese economy grows very rapidly and 75 per cent of the valueadded tax belongs to the central government, the central government's fiscal revenue has, however, grown much faster than that of the provinces. Enormous transfer payments have therefore become a new, powerful tool for the central government to influence the provinces.

In addition to tax revenue, the central government's control over the economy comes from the centrally controlled, large state-owned enterprises (SOEs), most of which are monopolistic. According to a release from China's StateOwned Assets Supervision and Administration Commission (SASAC), in 2009, the assets value of central government-controlled SOEs was RMB14.6 trillion (US $\$ 2.14$ trillion) - accounting for roughly 40 per cent of China's gross domestic product (GDP) in 2009 — while their profits were RMB980 billion. This further strengthens the capability of the central government.

Since the TSS reform, China's central-provincial government fiscal relationship has converged with that of Western countries. The central government controls most of the nation's fiscal resources and, financially, the provinces rely heavily on transfer payments. The difference between Structure 3 in China and Structure 1 in Western countries is in the personnel dimension. The dual top-down arrangements in personnel and fiscal dimensions have produced a super central government in China. Hence, without changing the status of the top-down personnel dimension, simply changing China's fiscal federalism and 
borrowing the top-down fiscal arrangement from Western countries to jump to Structure 3 from Structure 4 also risks the prevalence of vertical governmental opportunistic behaviour.

\section{Provincial-local government relations}

The TSS reform in 1994 was implemented only at the central-provincial level, not at the provincial-local level. Within a province, all local governments' revenues rely heavily on transfer payments from the provincial government. According to our investigation in 2004, transfer payments from the province accounted for 71.1 per cent of fiscal expenditure in a county in Sichuan. In the personnel dimension, higher-level governments nominate major county officials. This is a typical Structure 3 with strong higher-level government and weak lower-level government. This structure induces both types of governmental opportunistic behaviour, which reinforce each other.

The first is vertical governmental opportunistic behaviour of the provincial governments over the local governments. Due to the dual top-down arrangements in the two dimensions, local governments are too weak to play games with the province. The second is horizontal governmental opportunistic behaviour. Since the horizontal checks-and-balances mechanism for the government has not been well established in China, to solve their fiscal incapability problems resulting from the opportunistic behaviour of the higher-level governments, local governments have a strong incentive to act opportunistically and extract rents from the market. This in turn affects economic performance.

To solve the fiscal incapability problem of local governments in China, some have argued that local governments should have higher tax autonomy to match their expenditure. Nonetheless, as our analytical framework suggests, the universal arrangement is that lower-level governments rely financially on transfer payments from higher-level governments. The main solution is therefore not to devolve more tax autonomy, but rather to reform the top-down personnel arrangement to improve the bargaining power of lower-level governments and to institutionalise the transfer payment process to reduce opportunistic behaviour from higher-level governments. This change can be achieved through the development of grassroots democracy. If local officials could be elected rather than appointed by higher-level governments, and transfer payments could be institutionalised, an effective vertical balance between the provincial and local governments could be established. 


\section{The future evolution of China's intergovernmental relations}

China's intergovernmental relationships are undergoing rapid change. There are many positive changes that are reshaping and re-establishing the relationships. For instance, the Chinese government has officially endorsed 'socialist democratic politics'. Grassroots elections and internal democracy in the ruling Chinese Communist Party (CCP) are being widely practised and developed, and the rule of law and civil society are being established. The evolution of China's vertical intergovernmental relationships will have a profound influence on China's longterm development. How will China's vertical intergovernmental relationship evolve in the future? The framework developed in this chapter sees four major possible scenarios.

\section{Scenario 1: Structure 3-top-down fiscal and personnel dimensions}

This scenario means a continuation of the current intergovernmental relationship in the future. In this structure, the central government not only controls most of the nation's fiscal resources, it controls the appointment of the major officials of the provinces. Within the province, the provincial government also controls the appointment of the major local officials and most of the province's fiscal revenue.

This structure looks similar to that in the former planned economy. The substantive differences are the introduction of rule by law (as seen in the TSS) and the market economy. In Structure 3, the central government has very strong fiscal capability and authority to effectively realise the 'State's will' and to push forward with national reforms and development in areas such as social security, education and trans-regional infrastructure.

Nonetheless, as discussed previously, Structure 3 is not sustainable in the long run and also induces vertical and horizontal governmental opportunistic behaviour. The social cost and pressure of remaining in this structure would also be quite high. At this stage, many current economic and social problems in China - such as massive conflicts, petitions, farmer questions, local governments' huge debts and risks, distorted markets and corruption - are the results of the two types of governmental opportunistic behaviour. Without development of grassroots democracy and improving the checks-and-balances mechanism for government through constitutional rule, these problems might develop into crises. As Weingast (2005) points out, crisis shocks are the driving force for evolution towards a self-enforcing federalism or nation. To avoid possible economic and social crises and to build up the so-called 'harmonious society' in China, a sustainable intergovernmental relationship needs to be established. 


\section{Scenario 2: Structure 1(I)-a good market economy}

As far as we can see from the practices around the world, this structure is probably the most stable and sustainable one. It not only has a stable vertical structure, it has an effective horizontal checks-and-balances mechanism. China already has some of the conditions in place required for evolution to this structure.

In the two vertical dimensions, China's fiscal arrangement at the centralprovincial level is already very similar to that in Western countries. The key for China to shift to Structure l(I) is to reform its arrangement in the personnel dimension, or to develop its democracy. Although grassroots elections are developing steadily in China, they are still at a relatively early stage. To what level, and when, direct elections can develop in the future in China is still unclear.

At the horizontal level, China needs to establish effective checks-and-balances mechanisms at various levels of government through the rule of law, so that the market can function well. The expansion of civil society and liberty with rapid economic growth will allow the rule of law and democracy eventually to be well established in China.

\section{Scenario 3: Structure 1(II) - a bad market economy}

This structure looks sustainable in terms of vertical intergovernmental relationships, but is not an effective one for economic growth. This is an example of a bad market economy, in which the rule of law is not well established and the law institutionalises the privileges of interests groups, even though it has democracy. This would result in the prevalence of horizontal governmental opportunistic behaviour (Liu and Yang, 2001).

At present, vested interests - instead of ideology - have become the biggest impediment to China deepening its economic and political reforms. Corruption and social injustice are serious. The law has already institutionalised some privileges of interest groups and the market has some serious distortions. If this situation does not change, China is likely to evolve to this structure in the future. If constitutional rule cannot be established and liberty cannot be guaranteed, democracy alone will not be sufficient for eradicating corruption and the privileges of interest groups, since horizontal governmental opportunistic behaviour will prevail. This would result in poor economic performance and social injustice. Hence, this is a structure China should try to avoid. 


\section{Scenario 4: Structure 3 at the central-provincial level and Structure 1 at the provincial-local level}

This is a mixed structure with different relations at different levels of government. The central-provincial relationship would be Structure 3, while the provinciallocal relationship would be Structure 1 . This structure is very likely to occur in China in the future.

Since the central-provincial relationship is already at Structure 3, two further steps are needed to shift to this mixed structure. One is that grassroots democracy spreads further - up to the county level from the township and village levelin the near future. Another is that the fiscal relationship between provincial and local governments be institutionalised by the TSS as well. If this were to happen, the vertical intergovernmental relationships within each province would be Structure 1 and substantially similar to those in Western countries.

At the central-provincial level, the vertical relationship would not be substantially changed, but the horizontal checks-and-balances mechanism would be effectively established through a strengthening of the rule of law. This would significantly reduce both types of governmental opportunistic behaviour.

This mixed structure implies that China could develop a unique vertical intergovernmental arrangement deeply rooted in its 5000-year history, tradition, culture and vast population. This mixed structure also provides room for the central-provincial relationship to further evolve to Structure 1 from Structure 3 once conditions mature. This is consistent with China's gradual reform approach since 1978. In this mixed structure, avoiding vertical governmental opportunistic behaviour remains a major challenge and is dependent largely on the rule of law and the moral merit of the top leaders.

\section{Conclusions}

Based on the theory of self-enforcing federalism, this chapter has developed an analytical framework for intergovernmental relationships. A sustainable federal nation is conditioned by whether different levels of government can be balanced to prevent vertical governmental opportunistic behaviour between them. Different arrangements in the fiscal and personnel dimensions have different effects on governmental opportunistic behaviour and therefore on whether a federal nation is sustainable. In a democratic nation, fiscal transfer payments make local governments hostages to federal/national government influence. Meanwhile, it is equally essential to establish a checks-and-balances mechanism through the rule of law and democracy to prevent horizontal governmental 
opportunistic behaviour in the market. Economic performance is conditioned on preventing endogenous transaction costs resulting from these two types of behaviour.

In terms of fiscal arrangements, China's central-provincial relationship is already very similar to that in Western countries. The central government controls most of the nation's fiscal resources and, financially, the provinces rely heavily on transfer payments. The key difference between China and Western countries is in the personnel dimension. The dual top-down arrangements in the personnel and fiscal dimensions in China have resulted in a very strong central government. Preventing vertical governmental opportunistic behaviour is therefore a major challenge for China - and it is not sufficient to simply borrow the top-down fiscal arrangement from the West.

This chapter sees four major possible scenarios for the future evolution of intergovernmental relationships in China. The first is Structure 3-a continuation of the current dual top-down intergovernmental relationships. The second is Structure 1, with good rule of law, which is a structure like those in Western countries. This is probably the most sustainable structure observable in the world today. The third is Structure 1, without good rule of law, which is the structure in some Latin American countries. This is a structure that China needs to avoid. The fourth structure is a mixed one of Structures 1 and 3 , in which the central-provincial relationship is Structure 3 and the provinciallocal relationship is Structure 1. This mixed structure is very likely to emerge as grassroots democracy grows in China. It also provides room for further evolution to a unified Structure 1 with good rule of law in the more distant future.

\section{References}

Boadway, R. and Tremblay, J.-F. 2005, A theory of vertical fiscal imbalance, Working Paper, Queen's University, Kingston, Ontario.

Brennan, J. and Buchanan, J. 1980, The Power to Tax: Analytical foundations of a fiscal constitution, Cambridge University Press, New York.

Breton, A. 1996,Competitive Governments: An economic theory of politics and public finance, Cambridge University Press, Toronto.

Buchanan, J. 1965, 'An economic theory of clubs', Econometrica, vol. 33, pp. $1-14$. 
Courant, P., Gramlich, E. and Rubinfeld, D. 1979, 'The stimulative effects of intergovernmental grants: or why money sticks where it hits', in $\mathrm{P}$. Mieszkowski and W. Oakland (eds), Fiscal Federalism and Grants-in-Aid, The Urban Institute, Washington, DC, pp. 79-95.

de Figureiredo, R. J. and Weingast, B. R. 2005, 'Self-enforcing federalism', Journal of Law, Economics, and Organization, vol. 21, no. 1, pp. 103-35.

de Melo, L. 2000, 'Fiscal decentralization and intergovernmental fiscal relations: a cross-country analysis', World Development, vol. 28, pp. 365-80.

Dollery, B. 2002, 'A century of vertical fiscal imbalance in Australian federalism', History of Economics Review, vol. 36, pp. 26-43.

Faguet, J.-P. 2004, 'Does decentralization increase government responsiveness to local needs? Evidence from Bolivia', Journal of Public Economics, vol. 88, nos 3-4 (March), pp. 867-93.

Fisman, R. and Gatti, R. 2000, Decentralization and corruption: evidence across countries, Development Research Group, The World Bank, Washington, DC.

Fisman, R. and Gatti, R. 2002, 'Decentralization and corruption: evidence from US federal transfer programs', Public Choice, vol. 113, nos 1-2 (October), pp. 25-35.

Fornasari, F., Webb, S. and Zou, H. 2000, 'The macroeconomic impact of decentralized spending and deficits: international evidence', Annals of Economics and Science, vol. 2, pp. 403-33.

Fox, W. F. 2001, Decentralization in the United States: where has the country headed?, Paper submitted to the International Symposium on Fiscal Imbalance, Canada, 13-14 September.

Hamilton, A., Madison, J. and Jay, J. 1787, The Federalist Papers, Online, $<$ http://www.foundingfathers.info/federalistpapers/>.

Hicks, U. K. 1984,Federalism: Success or failure, Macmillan, London.

King, D. 1984,Fiscal Tiers: The economics of multi-level government, Allen \& Unwin, London.

Martinez-Vazquez, J. and McNab, R. M. 2003, 'Fiscal decentralization and economic growth', World Development, vol. 31, no. 9 (September), pp. 1597-616.

Musgrave, R. 1959, Theory of Public Finance: A study in public economy, McGraw, New York. 
China: The Next Twenty Years of Reform and Development

National Bureau of Statistics (NBS) 2009, China Statistical Yearbook 2009, China Statistics Press, Beijing, p. 263.

North, D. 1987, 'Institutions, transaction costs, and economic growth', Economic Inquiry, vol. 25, pp. 419-28.

North, Douglas., and Weingast, Barry, 1989, “Constitutions and Commitment: The Evolution of Institutions Governing Public Choice in SeventeenthCentury England", Journal of Economic History, 49, pp. 803-32.

Oates, W. 1972,Fiscal Federalism, Harcourt Brace Jovanovich, New York.

Qian, Y. and Roland, G. 1998, 'Federalism and the soft budget constraint', American Economic Review, vol. 88, no. 5. pp. 1143 - 62.

Qian, Y. and Weingast, B. 1997, 'Federalism as a commitment to preserving market incentives', The Journal of Economic Perspectives, vol. 11, no. 4 (Autumn), pp. 83-92.

Scott, D. A. 1952, 'The evaluation of federal grants', Economica, vol. 19, no. 2, pp. 377-94.

Seabright, P. 1996, Accountability and decentralization in government: an incomplete contracts model', European Economic Review, vol. 40, pp. 61-89.

Shirk, S. 1993, The Political Logic of Economic Reform in China, University of California Press, Berkeley.

Smith, A. 1776, An Inquiry into the Nature and Cause of the Wealth of Nations, University of Chicago Press.

Stein, Ernesto, 1999, 'Fiscal decentralization and government size in Latin America', Journal of Applied Economics, vol. 2, no. 2. pp. 375 - 91.

Sun, L. 2004, 'A review on tax sharing system at its 10th anniversary' [in Chinese], The 21st Century Report, 10 November.

Thiessen, U. 2003, 'Fiscal decentralization and economic growth in high-income OECD countries', Fiscal Studies, vol. 24, no. 3 (September), pp. 237-74.

Treisman, D. 2000, 'The causes of corruption: a cross-national study', Journal of Public Economics, June.

Liu, W-M., and Yang, X., 2001: “Good Capitalism Versus Bad Capitalism: Effects of Political Monopoly of the Ruling Elite on the Extent of the Market, Income Distribution, and Development", Working Paper, Department of Economics, Monash University, No. 08/01. 
Wallin, B. A. 2001, Forces behind centralization and decentralization in the United States, Paper submitted to the International Symposium on Fiscal Imbalance, Canada, 13-14 September.

Watts, R. L. 1999, Comparing Federal Systems, Second edition, Queen's University, Kingston, Ontario.

Weingast, B. R. 2005, 'The constitutional dilemma of economic liberty', The Journal of Economic Perspectives, vol. 19, no. 3. pp. 89 - 108

Yang, X. 2001,Economics: New classical versus neoclassical framework, Blackwell Publishers Ltd, New York.

Zhang, Y. 2005, The direction of China's reform on fiscal transfer payments learning from international comparison: a theoretical framework on intergovernmental relationship, Research Report of Development Research Centre of the State Council, vol. 32, Beijing.

Zhang, Y. 2008, 'The intergovernmental assignment of expenditure and revenue', Comparison of Economic and Social System [in Chinese], vol. 2.

Zhang, Y. 2009, 'Central-local governmental relationship: a theoretical framework and its application', Comparison of Economic and Social System [in Chinese], vol. 2 . 